\title{
イヌの実験的歯肉炎における不溶性免疫複合物の動態
}

\author{
山下 智* 原 耕 二* 野原広美** \\ $*$ 新潟大学歯学部歯科保存学第 2 教室 \\ (主任 : 原 耕二教授) \\ ** 新潟大学歯学部口腔生化学教室 \\ （主任 : 野原広美教授） \\ (昭和 59 年 3 月 20 日受付)
}

\section{Insoluble Immune Complexes in Experimental Gingivitis of Dogs}

\author{
Satoshi YAMASHITA*, Kohji HARA* and Hiroyoshi NOHARA** \\ Departments of Periodontology* (Director : Prof. Kohji HARA) and Oral \\ Biochemistry** (Director : Prof. Hiroyoshi NOHARA) Niigata University \\ School of Dentistry
}

This study was undertaken to examine the levels of insoluble immune complexes in healthy and inflamed gingiva by measuring citrate buffer-elutable IgG.

After establishment a clinically healthy gingiva by continuous toothbrushing for 6 weeks, the experimental gingivitis was induced by placement of silk floss ligature to accelerate plaque formation for 1 week, 1 and 3 months. The excised gingiva was prepared by the elution procedure with PBS and citrate buffer.

The concentration of PBS-elutable IgG in gingiva was measured by SRID, besides the citrate bufferelutable IgG was determined by ELISA and RIA.

As a results ;

1) The amount of PBS-elutable IgG had a tend-

Key words : Insoluble immune complex, Experimental gingivitis, Citrate buffer-elutable IgG, ELISA, RIA

要旨:イヌに実験的歯肉炎を誘発させ，歯肉組織中の不溶性免疫複合物の経時的変動を ELISA と RIA の二つの免 疫学的測定法を用いて検索した。すなわち健康歯肉を確立後， 口腔内を 4 区分し，それぞれ 1 週，1 力月， 3 力月病期 の歯肉炎を惹起させた。屠殺時, 採取した歯肉を citrate buffer で溶出し，この画分中の IgG 量を ELISA ならびに RIA で測定した。その結果, その IgG 量は健康時に比べ炎症歯肉で有意に上昇し, 炎症の経過とともに増加の傾向を 示した。また ELISA とRIA とでは両者間に高い相関性のあることが確認された。

索引用語 : 不溶性免疫複合物, 実験的歯肉炎, クエン酸緩衝液可溶性 $\mathrm{IgG}$, 䤉素免疫測定法, ラジオイムノアッセイ 


\section{緒 論}

歯周疾患において体液性免疫反応が重要な位置を占め ていることは，多くの研究者により報告されている。た とえば，歯周組織が細菌あるいはその代謝産物などの抗 原刺激を持続的にうけ, 結果的に Immunoglobulin を産 生するリンパ球や形質細胞の増加をきたすこと1や，補

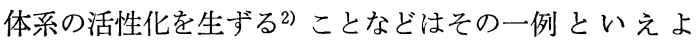
う。著者の一人山下 ${ }^{3)}$ は，既にイヌを実験対象とし，そ の歯肉組織中の各種 Immunoglobulin の動態を病期に より経時的にとらえ, 健康時に比べ $\operatorname{Ig} M$ が 1 週病期で, IgG が 3 カ月病期で有意に増加していることをつきとめ た。近年, さらにある種の細菌に特異的な IgG の力価 を測定することも試みられ4), この種の研究も特異抗体 の検索を中心に発展しつつあるように思われる。

一方，歯肉組織中では細菌抗原と局所的に産生された 免疫グロブリンとの間に抗原抗体反応が生じ，その結果 免疫複合物ができることが知られている。中でも，組織 に沈着した不溶性免疫複合物の存在は, 補体の関与とと もに歯周組織に障害をもたらす Arthus 型アレルギー反 応が生じていることを示唆しており ${ }^{5)}$ ，その動向が注目 されている。

このため今回，著者らはイヌに実験的歯肉炎を誘発さ せ, 歯肉組織中の不溶性免疫複合物の経時的変動を Enzyme-linked immunosorvent assay (ELISA) と Radioimmunoassay (RIA) の二つの免疫学的測定法を用 いて検索する目的で本実験を行った。

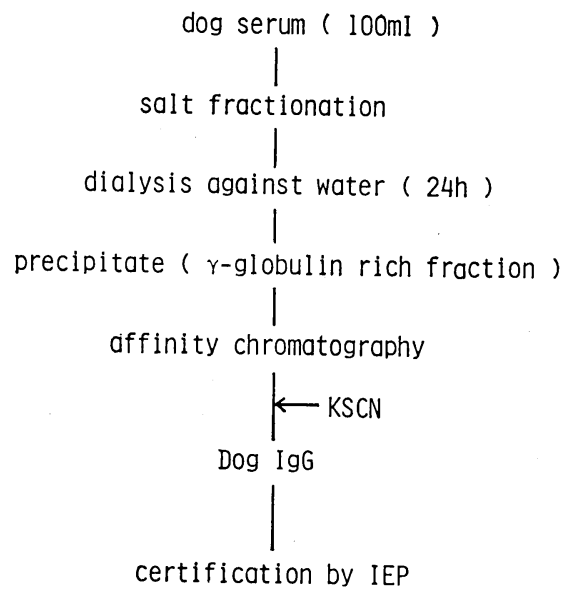

Fig. 1 Purification of $\operatorname{dog} \operatorname{IgG}$

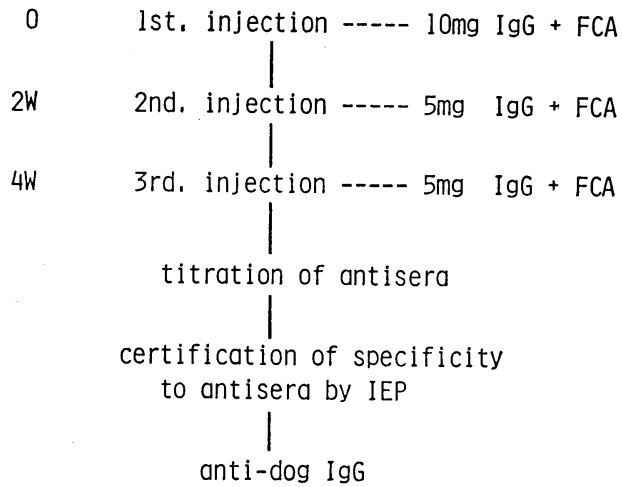

Fig. 2 Prepartion of anti-dog IgG (produced in rabbit)

\section{研究材料と方法}

\section{1. イヌ IgG の精製}

Fig. 1 に示すとおり, 新鮮血より得たイヌ全血清 100 $\mathrm{m} l$ を生理的食塩水で 2 倍に希釈後, $40 \%$ 硫安で 1 回, 33 \%硫安で 2 回塩析した。次いでその沈渣を $0.01 \mathrm{M}$ PBS （pH 7.4）で溶解後, 24 時間純水に対して透析し約 500 $\mathrm{mg}$ の不溶化した $\gamma$ グロブリン画分を得た。一方, CNBr-activated Sepharose ${ }^{\circledR B}$ にリガンド (抗体) と して Miles Lab. 製の抗イヌ IgG 家鬼血清 (IgG 画分) を固定化させることにより，イヌ $\operatorname{IgG}$ を特異的に吸着さ せるアフィニティーカラム $(\phi 1 \times 5 \mathrm{~cm})$ を調製した。固 定化した抗体蛋白量の 1.5 倍の ケグロブリン画分を使用 し，原則にそって，アフィニティークロマトグラフィー を行ったのち, KSCN で溶出し, 総蛋白量 $65 \mathrm{mg}$ の精製 イヌ IgG を得た。このものは Immunoelectrophoresis (IEP) による検定で特異性を確認した。

\section{2. 抗イヌ IgG の調製}

Fig. 2 は抗イヌ IgG の調製法を示したもので，さき に精製したイヌ IgG $10 \mathrm{mg}$ を等量の Freund's Complete Adjuvand (FCA) と共に家鬼の四肢掌に 1 力所 $0.1 \mathrm{ml}$ ずつ皮下注射した。次いで各 $5 \mathrm{mg} の \mathrm{IgG}$ に同様な処理 を施した後, 2 週間隔で 2 回今度は家鬼の背部に追加投 与した。最終回の注射より 1 週後に家鬼の耳より試験採 血し，遠心上清を Ouchterlony 法で titration した。

その結果, titer 上昇を認め, 次いで特異性の検定を IEP で行ったところ, 特異性を確認したので, 家鬼を漆 血し, 得られた血清を $11,000 \times g$ で 30 分間遠沈し, 特 異抗血清を得た。

このものは分析に供するまで $-70^{\circ} \mathrm{C}$ に凍結保存し 
た。

\section{3. 実験的歯肉炎の発生}

体重が約 $10 \mathrm{~kg}$ 前後ですべて雄の雑種成犬 4 頭を使 用, 上顎 $\mathrm{I}_{3} \sim \mathrm{P}_{4}$, 下顎 $\mathrm{I}_{3} \sim \mathrm{M}_{1}$ の唇煩側歯肉を実験対象 とした。Fig. 3 は実験的歯肉炎の概要を示したもので, 各犬共口腔内を 4 区分し，異った病期の歯肉炎を発生さ せる様考慮した。実験操作に関しては，著者が以前に報 告したと同じ方法で行い，屠殺 時にプラーク蓄積 3 カ 月, 1 力月, 1 週間各時期の炎症歯肉と臨床的健康歯肉 が同時に採取できるようにした。採取した歯肉は余分の 血液成分を生理的食塩水で十分に洗い流した後, $-70^{\circ} \mathrm{C}$ にて凍結保存した。なお，採取した各病期の歯肉は一部 組織学的に観察した。

\section{4. 歯肉抽出液の調製}

Fig. 4 は歯肉抽出液の調製法を示したものである。ま ず著者の一人山下がすでに報告した方法に準じて行った もので，歯肉を磨砕，PBS に溶出，凍結と融解をくり返 乙, 超音波処理後, 遠沈して得たものを PBS 抽出画分 (Fraction 1; F-1) とした。残った沈渣に対し PBS にて同じ溶出操作を 7 回繰り返して得た画分をそれぞれ Fraction 2〜Fraction 8 とした。更に残った沈渣に対し今 度は $0.02 \mathrm{M}$ citrate buffer (pH 3.2) を加えて酸可溶成 分を溶出後, 得られた画分を Fraction $9 ; \mathrm{F}-9$ とした。な お, Fraction 1〜Fraction 8 は Amicon PM-10を用い
Time

0

$2 M$

$3 M$

$4 M$

5M clinically

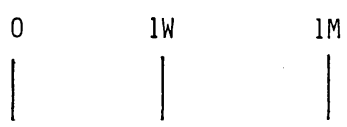

(scal ing)

tooth brushing

1.5M establishment of healthy gingiva (beginning of experiment)
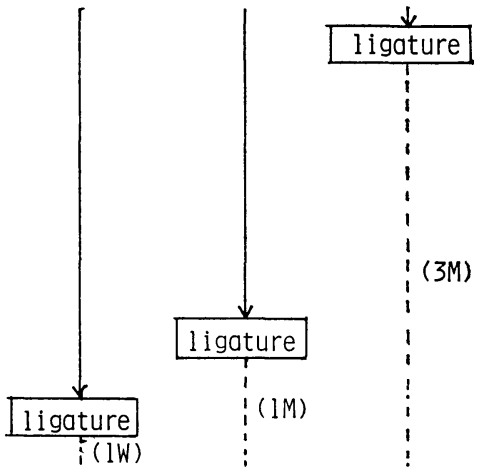
heal thy gingivo

Fig. 3 Induction of experimental gingivitis

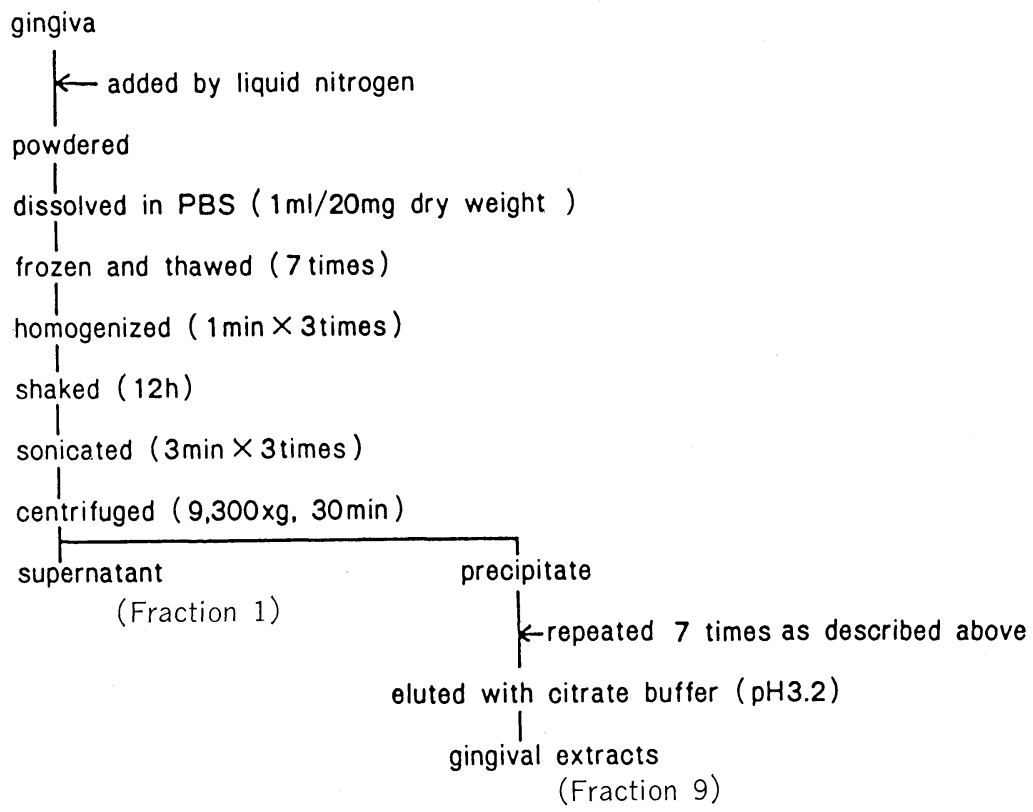

(Fraction 1)

(Fraction 9)

Fig. 4 Preparation procedure of gingival extracts 


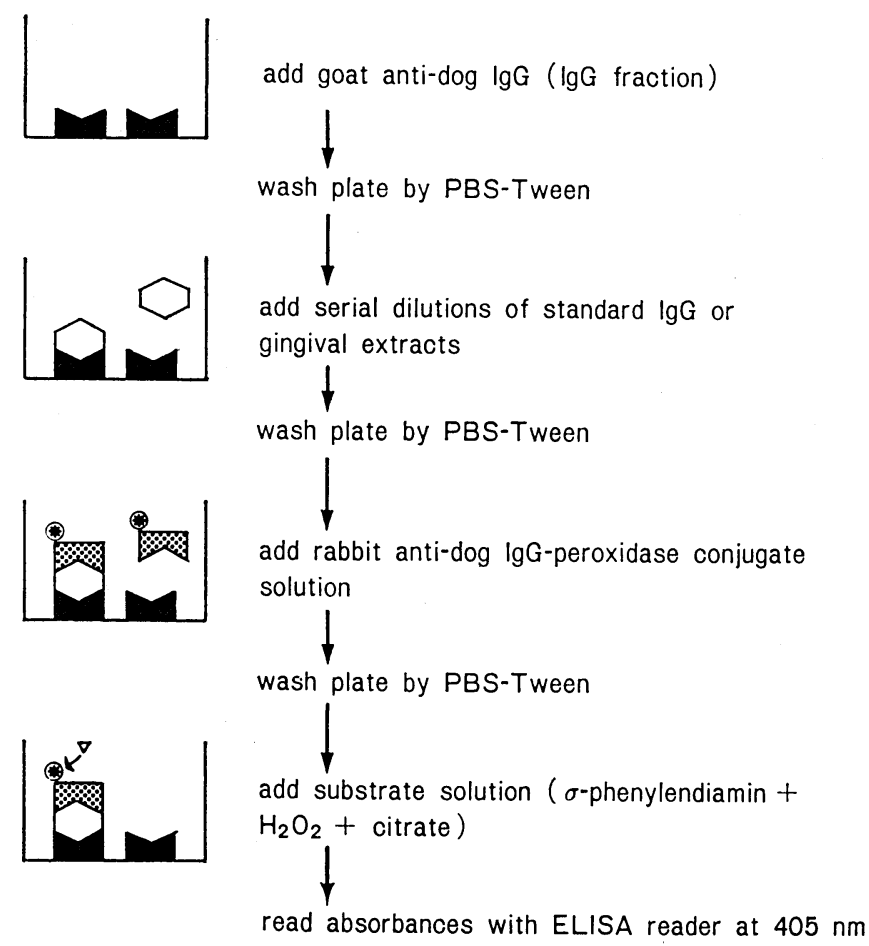

Fig. 5 Microtiter ELISA method

$0.5 \mathrm{~m} l$ まで限外濾過し, $0.01 \% \mathrm{NaN}_{3}$ を加えたものを一 $20^{\circ} \mathrm{C}$ にて保存した。また Fraction 9 は, $\mathrm{pH}$ を中性に もどしたのち, $-20^{\circ} \mathrm{C}$ で保存した。

\section{IgG の定量方法}

\section{1) Single radial immunodiffusion}

著者らが以前報告した通り, Mancini ( $^{6}$ の方法 (1965) に準じて PBS 抽出画分 (F-1) 中の IgG を定量した。

\section{2) Enzyme-Linked Immunosorbent assay}

\section{(ELISA)}

Goldsmith $^{7}$ の方法 (1981) に準じて citrate buffer 抽 出画分 (F-9) 中の IgG 量を測定した。方法に関する詳 細は, Fig. 5 に示したとおり次のようになる。

\section{a) 第 1 抗体の Coating}

即ち Miles Lab. 製の抗イヌ全血清 (ヤギ) の IgG 画 分を, アフィニティークロマトグラフィー用担体である Protein A-Sepharose CL-4B (Pharmacia Fine Chemicals）により精製した後，これを Coating buffer [0.1
$\mathrm{M} \mathrm{NaHCO}_{3}(\mathrm{pH} 9.6) / 0.002 \% \mathrm{NaN}_{3}$ ] で 140 倍希釈, Gilson 社製 Pipetman ${ }^{\circledR}$ 用いて microtiter plate (NUNG)に に well 当り $100 \mu l$ (抗体量 $2 \mu \mathrm{g}$ ) ずつ Coating した。次いで $4^{\circ} \mathrm{C}$ で1晚インキュベートした後, PBSTween を入れた洗浄ビンを用いて plate を 5 回洗浄寸 ることにより well に吸着しなかった余剩の抗体を除い た。

\section{b）試料及び標準 IgG の Coating}

さらに Fig. 5 はその方法を示したもので, 歯肉抽出 液及び標準 IgG の連続希釈系を Diluent-buffer $[0.02$ M PBS (pH 7. 4) $/ 1 \mathrm{mM} \mathrm{MgCl} / 0.05 \%$ Tween $/ 1 \% \mathrm{BSA}$ ] で調製し, プレート 1 well 当り $200 \mu l$ ずつ注入した。 そして再び $4^{\circ} \mathrm{C}$ で 1 晚インキュベート後, プレートを再 度 PBS-Tween により 5 回洗浄した。

\section{c）酵素標識抗体の Coating}

即ちその方法は, Fig. 5 に図示しており, peroxidase 標識抗イヌ IgG 家鬼血清 (Miles Lab.)を Diluent-buff- 
er で 200 倍に希釈後, 1 well 当り $200 \mu l$ ずつ注入した。 室温で 2 時間インキュベートし, 再度 PBS-Tween で plate を洗浄し余剩の抗血清を除去した。

\section{d）基質の添加及び酵素反忍}

方法は Fig. 5 の最下段に図示したもので, 基質として $\sigma$-phenylendiamine を使用, $\mathrm{H}_{2} \mathrm{O}_{2}$ と共に $0.1 \mathrm{M}$ クエン 酸に混ぜこれをプレート 1 well 当り $200 \mu l$ ずつ注入し, 90 分間酵素反応を行わせた。

\section{e ) 吸光度測定及び IgG 量の算出}

MTD 12 型マイクロプレート光度計（コロナ社製）を 用いて各 well ごと $405 \mathrm{~nm}$ の吸光度で測定した。この 結果, Fig. 6 亿示すと打り, 定量可能範囲は, 5〜150 ng/ well であり, 得られた標準曲線より試料中の IgG 量を 算定した。

\section{3) Radioimmunoassay (RIA)}

著者らは, BF 分離法 (B は標識蛋白, $\mathrm{F}$ は遊離蛋白) として入江ら ${ }^{8)}$ の二抗体法 (1974) 及び Desbuquois ら9) の PEG 法 (1971) を組合せた方法で citrate buffer 抽 出画分 (F-9) 中の IgG 量を測定した。

\section{a) イヌ IgG の ${ }^{125}$ 標識}

RIA にさきだち, イヌ IgG の ${ }^{125}$ I 標識を行った。この 方法は, Hunter と Greenwood ${ }^{10)}$ (1962)のクロラミン T法に準じ，これを一部改変したものである。すなわ ち, シオノギチューブにクロマト精製イヌ IgG $5 \mu l$ (蛋 白量 $2.5 \mu \mathrm{g}$ ）を入れ, そこにクロラミン T 液 $10 \mu l$ （ク ロラミン T $20 \mu \mathrm{g})$ 及び Na ${ }^{125} \mathrm{I} 5 \mu l(500 \mu \mathrm{Ci})$ を 0.25 M phosphate buffer (pH 7.4) と共に加え 30 秒間擋拌 しながら反応させた。その後 Sodium metabisulfate 50 $\mu l(100 \mu \mathrm{g})$ と $10 \% \mathrm{KI} 10 \mu l$ をチューブに加え, 反応を 停止させた。

続いて標識蛋白と free の $\mathrm{NaI}$ を分離するため, Sephadex G-25 を用いてゲル濾過を行なった。

即ち反応液を Sephadex G-25 column $(\phi 0.6 \times 25 \mathrm{~cm})$ にかけたのち, $0.25 \%$ BSA 加 $0.01 \mathrm{M}$ PBS (pH 7.4) で 溶出し, 各画分の放射活性を測定したところ 2 つのピー クを得た。その結果, 第一ピークが ${ }^{125} I$ 標識 イヌ IgG であることを確認し，その中でカウントが最大の画分を 分注してこれを $-70^{\circ} \mathrm{C}$ で保存した。尚, この画分中の IgG 量は, $1167.5 \mathrm{ng}(400 \mu l)$ であり, IgG の比放射活 性は $17.5 \mu \mathrm{Ci} / \mu \mathrm{g}$ であった。

\section{b ）第一抗体の至適希釈量の決定}

抗血清として第一抗体は, Miles Lab. の抗イヌ IgG （家鬼）を，第二抗体としては第一ラジオアイソトープ 研究所製の家鬼 $ノ$ グロブリン抗血清 (山羊) と正常家

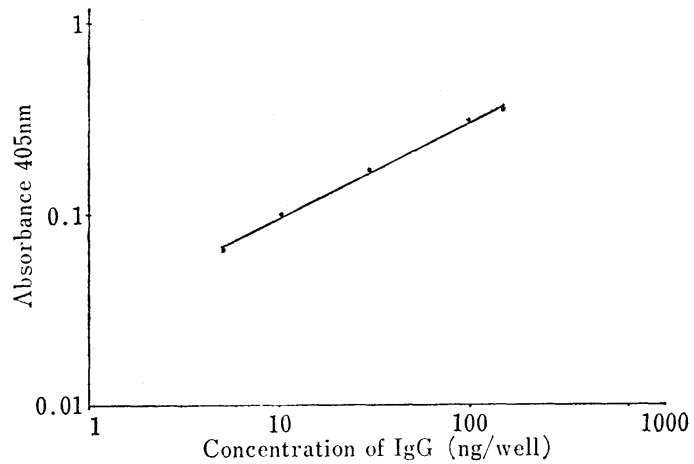

Fig. 6 Standard curve for IgG using ELISA (Goldsmith, 1981)

鬼血清を set したものを使用した。

操作手順として, Fig. 7 に示すとおり最初に第一抗体 の抗イヌ IgGを 0.01 M PBS (pH 7.4) で，それぞれ 1,000 倍, 4, 000 倍, 16,000 倍, 64,000 倍に希釈し, これ をシオノギチューブに $0.1 \mathrm{~m} l$ ずつ分注した。続いて ${ }^{125} \mathrm{I}$ 標識イヌ IgG $0.25 \% \mathrm{BSA}$ を含む PBS で希釈しそれ ぞれチューブに $0.1 \mathrm{~m} l$ ずつ加えた $(10,000 \mathrm{cpm} / 1$ チュ ーブ)。さらに SD (25 mM EDTA, 0.5\% BSA を含む PBS）を $0.3 \mathrm{ml}$ ずつ加え十分粯拌した後, $4^{\circ} \mathrm{C}$ で 24 時

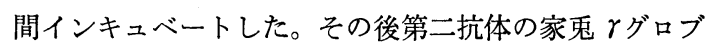
リン抗血清 (山羊) と正常家鬼血清をそれぞれ $0.1 \mathrm{~m} l$ ずつ, $5 \%$ PEG (半井化学)を $0.7 \mathrm{~m} l$ ずつ加え䧗挥のの ち, 再び 24 時間インキュベートした。そして $2,200 \times g$ で, 30 分間遠心後, 上清を吸引し, チューブの壁につい た余剩の反応液を綿棒で清拭した。この沈渣の $\mathrm{cpm}$ を オートウエルガンマシステム (アロカ社) で測定し，B/ $\mathrm{T}$ を算出した結果, $\mathrm{B} / \mathrm{T}=50$ となる第一抗体の希釈倍数 は 1,000 倍となったため, 以下の実験はすべてこの希釈 倍数で行った。

\section{c）標準曲線の作成と試料の測定}

試料の測定と同時に Fig. 8 に示すごとく, 標準曲線の 作成を行った。操作手順は, 既知の各種 濃度 $0.5 \sim 512$ ng の標準イヌ IgG ないしは歯肉抽出液を PBS で希釈 調製したものをチューブに各 $0.1 \mathrm{~m} l$ ずつ入れ，さらに 1,000 倍希釈の第一抗体, ${ }^{125}$ 標識イヌ $\mathrm{IgG} 0.1 \mathrm{~m} l$ ず つ, $\mathrm{SD}$ を $0.3 \mathrm{~m} l$ ずつそれぞれ加え 24 時閒インキュベ 一トした。以後の操作は前述の第二抗体加入後の操作手 順と全く同一に行った。この結果, $5 \sim 320 \mathrm{ng} / \mathrm{m} l$ の範囲 でイヌ IgG の測定が可能となり,この標準曲線より試料 中の IgG 量を算出した。 


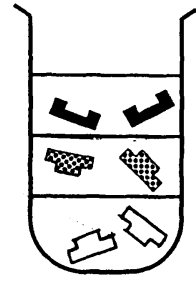

add $-\left[\begin{array}{l}\text { rabbit anti-dog } \lg G \text { (IgG fraction) } \\ 125 \mid-d o g \lg G\end{array}\right.$

serial dilutions of standard IgG or gingival extracts

incubate at $4^{\circ} \mathrm{C}$ for $24 \mathrm{~h}$

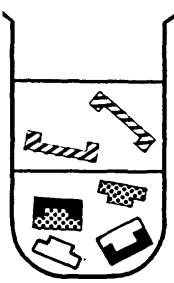

$\downarrow_{\text {add }}^{\text {goat anti-rabbit immunoglobulin }} \begin{aligned} & \text { normal rabbit serum } \\ & 5 \% \text { PEG }\end{aligned}$

incubate at $4^{\circ} \mathrm{C}$ for $24 \mathrm{~h}$

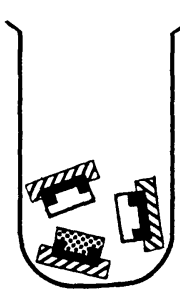

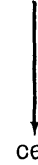

centrifuge $30 \mathrm{~min}$ at $2,200 \mathrm{xg}$

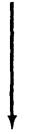

count in a gamma counter (precipitate)

Fig. 7 Radioimmunoassay

: rabbit anti-dog IgG (IgG fraction)

: ${ }^{125} \mathrm{I}-\mathrm{dog}$ IgG

: dog IgG

races: goat anti-rabbit immunoglobul in

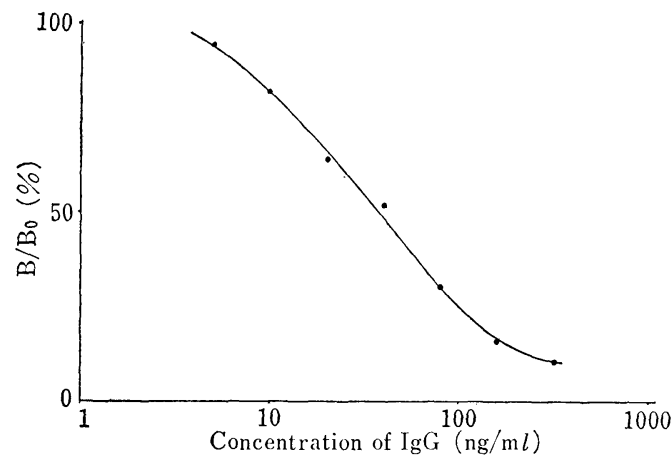

Fig. 8 Standard curve for IgG using RIA

\section{6. 蛋白量及び DNA 量の測定}

蛋白量は Lawry ら ${ }^{11)}$ (1951) の方法に基づき, BSA を標準蛋白として測定した。一方, DNA 量は Burton ${ }^{12)}$ （1956）の変法で測定した。

\section{結果}

1）実験的歯肉炎の各病期における肉眼的ならびに組 織学的所見

各病期のいずれの歯肉においても特徴ある病態を呈し た。すなわち，健康歯肉と設定した部位は，実験期間を 通して徹底したブラッシングの励行によりプラークの付 着がまったくみられず，健康歯肉が維持できた。また， 
Table 1 Levels of PBS and citrate buffer-elutable IgG $(\mu \mathrm{g} / 100 \mu \mathrm{g}$ DNA)

\begin{tabular}{|c|c|c|c|c|}
\hline & 0 & $1 \mathrm{~W}$ & $1 \mathrm{M}$ & $3 \mathrm{M}$ \\
\hline \multirow[t]{2}{*}{ SRID } & $88.2 \pm 17.3$ & $101.1 \pm 16.9$ & $156.8 \pm 34.2$ & $183.2 \pm 21.8$ \\
\hline & \multicolumn{4}{|c|}{$*$} \\
\hline \multirow[t]{2}{*}{ ELISA } & $0.148 \pm 0.029$ & $0.411 \pm 0.039$ & $0.671 \pm 0.051$ & \multirow[t]{2}{*}{$0.774 \pm 0.070$} \\
\hline & & * & & \\
\hline \multirow[t]{2}{*}{ RIA } & $0.116 \pm 0.035$ & $0.306 \pm 0.060$ & $0.326 \pm 0.063$ & \multirow[t]{2}{*}{$0.426 \pm 0.079$} \\
\hline & & $*$ & & \\
\hline
\end{tabular}

* : significant at $\mathrm{P}<0.05$

Values are means $\pm \mathrm{S}$.E.

Table 2 Levels of citrate buffer-elutable/PBS-elutable IgG (\%)

\begin{tabular}{ccccc}
\hline & \multicolumn{1}{c}{0} & $1 \mathrm{~W}$ & $1 \mathrm{M}$ & $3 \mathrm{M}$ \\
ELISA & $0.189 \pm 0.024$ & $0.307 \pm 0.051$ & $0.527 \pm 0.067$ & $0.520 \pm 0.091$ \\
RIA & $0.174 \pm 0.039$ & $0.231 \pm 0.052$ & $0.277 \pm 0.037$ & $0.261 \pm 0.037$ \\
\hline
\end{tabular}

* : significant at $\mathrm{P}<0.05$

N.S. : not significant at $\mathrm{P}>0.05$

Values are means $\pm \mathrm{S}$. E.

組織学的には，歯肉溝の上皮脚は認められず，歯肉結合 組織中の炎症性細胞浸潤，血管の拡張も殆んどみられな かった。一方, プラーク蓄積 1 週間後の歯肉所見では, 軽度の発赤, 腫脹が認められ, 歯頸部に少量のプラーク が蓄積していた。組織学的には，歯肉溝上皮直下結合組 織中に好中球の浸潤，集積が生じ，血管の拡張も顕著で あった。プラーク蓄積 1 カ月後における歯肉の炎症は, より高度となり, 組織学的には少量の好中球, 形質細胞 の出現のほか, リンパ球主体の細胞浸潤と歯肉固有層中 の結合組織線維の破壊が著しくなった。プラーク蓄積 3 カ月後になると多量のプラークが歯頸部に付着し, 高度 の歯肉炎の様相を呈した。組織学的には, 形質細胞及び リンパ球の浸潤が主体を占め，また歯肉結合組織線維の 破壊が強く認められた。

\section{2）実験的歯肉炎の各病期における歯肉抽出液中の}

\section{PBS 可溶性 IgG について}

各病期に打ける歯肉の PBS 溶出画分 (F-1) 中の IgG 量を SRID で測定し, その結果を Table 1 の上段に示し た。これによると健康歯肉での值は, $88.2 \pm 17.3 \mu \mathrm{g} / 100$ $\mu \mathrm{g}$ DNA であったのに対し, 炎症歯肉では経時的に漸次 増加の傾向を示し, 特に 3 カ月病期の歯肉では $183.2 \pm$ $21.8 \mu \mathrm{g} / 100 \mu \mathrm{g}$ DNA となり, 健康歯肉との間に統計学 的な有意差が認められた $(\mathrm{P}<0.05)$ 。

3）実験的歯肉炎の各病期における歯肉抽出液中の citrate buffer 可溶性 IgG について

各病期における歯肉の citrate buffer 溶出画分 (F-9) 中の IgG は, Table 1 の中で ELISA 值は中段, RIA 值 は下段に示した。ELISA では健康歯肉が $0.148 \pm 0.029$ $\mu \mathrm{g} / 100 \mu \mathrm{g}$ DNA に対して, 炎症歯肉では 1 週で $0.411 \pm$ $0.039,1$ 力月で $0.671 \pm 0.051,3$ 力月で $0.774 \pm 0.070$ と経時的に漸次増加の傾向を示した。健康歯肉に対し て, 炎症歯肉ではいずれの病期も統計学的に有意差が認 められた $(\mathrm{P}<0.05)$ 。一方, RIA の場合も, ELISA の結 果と同様な傾向を示した。すなわち, 健康歯肉の $0.116 \pm 0.035 \mu \mathrm{g} / 100 \mu \mathrm{g}$ DNA に対し, 炎症歯肉では 1 週で $0.306 \pm 0.060,1$ カ月で $0.326 \pm 0.063,3$ 力月で $0.426 \pm 0.079$ といずれも有意に増加していた（P< 0.05 )。 


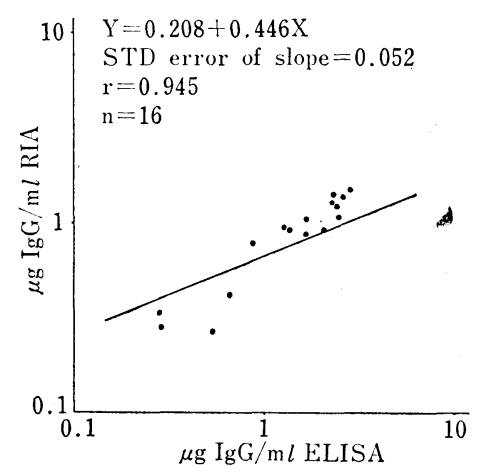

Fig. 9 Comparison of ELISA versus RIA determination of $\operatorname{dog}$ IgG

\section{4）歯肉抽出液中の PBS 可溶性 IgG に対する citrate buffer 可溶性 IgG の割合}

Table 2 は ELISA 及び RIA の值を示す。ELISA では 健康歯肉 $0.189 \%$ に対し，病期 1 週，1 力月， 3 力月で はそれぞれ $0.307 \% ， 0.527 \% ， 0.520 \%$ となり，1 カ月 及び 3 力月で統計学的に有意な増加が認められた $(\mathrm{P}<$ 0. 05)。一方, RIA では健康歯肉の $0.174 \%$ に対し， 1 週 で $0.231 \%$ と増加したものの, その後 1 力月, 3 力月で は 0.277\%, 0.261\% と若干の増加にとどまった。

\section{5） ELISA と RIA の相関性}

Fig. 9 は, ELISA と RIA による citrate buffer 可溶 性 IgG 量の相関関倸をあらわしたものである。すなわ ち相関保数 $\mathrm{r}=0.945$ となり, 両者間に高い相関性のあ ることが証明された。また, $\mathrm{r}$ の有意性の検定を行った ところ, $\mathrm{t}=10.81$ ， しかるに $\mathrm{n}=16$ となり， $1 \%$ の危険度 における $\mathrm{t}$ 值は 2.977 であることから $\mathrm{r}=0.945$ はすこ ぶる有意義であり， ELISA と RIA の相関の存在が十分 確認された。

\section{考察}

著者の一人山下は既に，イヌに実験的歯肉炎を惹起さ せその歯肉中の各種免疫グロブリン ( $\mathrm{IgG}, \operatorname{Ig} \mathrm{A}, \operatorname{Ig} \mathrm{M})$ を定量した ${ }^{3)}$ 。その結果, IgG がプラーク著積 1 カ月, 3 カ月で有意に増加したのに対し, $\operatorname{Ig} M$ は 1 週で急増し, その後はやや減少傾向を示した。これらの事実より免疫 細胞の IgM $\rightarrow \operatorname{IgG}$ 変換13) あるいは白血球由来のライソ ゾーム酵素による IgM の構造変化 ${ }^{14)}$ が考えられる。

Page \& Schroeder ${ }^{1)}$ はその分類の中で初期病変の主役 は, プラークなどの外来抗原の内部抗散により遊走活性 を得た多形核白血球であるとのべており，これが局所の
免疫応答によって惹起される防御的あるいは破壊的反応 をコントロールしていることも理解できる。多形核白血 球の存在は, 組織障害の機構を知る上で重要な因子であ る。特に, 歯肉組織中に存在する細菌の代謝産物や様々 な組織抗原などは組織中の Ig M, IgG と反応し免疫複 合物 (Immune Complex) を形成する。そして結果的に Arthus 型のアレルギー反応を惹起させ白血球の食食 を促進する ${ }^{15)}$ 。これにより多形核白血球の脱顆粒が生じ ライソジーム酵素の放出とともに組織破壊が生ずる。

Arthus 型アレルギー反応における免疫複合物の 役 割 は重要であるが, この免疫複合物の生物活性としては, 組織に沈着して障害をもたらすほか, 補体系の賦活化, マクロファージの活性化, リンパ球のコントロールなど 血液成分に対して多種多様に作用する ${ }^{16)}$ 。本来生体中に 存在する免疫複合物は, 血中免疫複合物の型であり, 多 くはこのままマクロファージ (脾臓, リンパ節), Kupffer (肝臟) など網内系の細胞により食食される。しかし 免疫複合物の性状によっては, 補体結合性をもっている 抗体や, 強い陰性荷電をもつ抗原を含む場合は組織に沈 着しやすいとされ，歯肉組織にも同様の現象が生じてい る可能性がある。むろん腎や肺などの臟器は, 体内の濾 過を司る構造上の特徵を有するため歯肉などよりもはる かに免疫複合物が沈着しやすい。しかし, 歯肉は陽性荷 電を示すコラーゲン線維を多く含有し，これが強い陰性 荷電を持つDNA との間に化学的な結合をしやすく,免疫 複合物沈着の原因の一つとして考えられる。一般に腎炎 などでは血中の免疫複合物が増加し, その炎症程度と免 疫複合物 (DNA-抗 DNA 抗体) 量に相関性があるという 報告17) もある。一方, 歯周疾患の場合免疫複合物がその 組織中に存在することを示唆した報告 ${ }^{18)}$ はみられるもの の, それを組織学的あるいは生化学的に解明し, 歯周疾患 の程度とどのような因果関係があるかを証明した例は少 ない。Clagett ら ${ }^{19)} は$ anti-double stranded DNA 抗体 とポケットの媣さとの相関はみられたものの, 不溶性免 疫複合物を $\mathrm{pH} 3.2$ の citrate buffer で解離させ構成抗 原である IgGを RIA で測定した結果, ポケットの梁さ との間に有意な相関はみられなかったとのべている。ま た, イヌ歯肉による螢光抗体法で C3, IgG の局在も同 時に確認し得たが, それがきわめて微量であるため, 歯 肉中に局在する不溶性免疫複合物の生物学的活性は, 歯 周疾患を惹起するには非常に弱いと報告している。一 方, 金城 ${ }^{20)}$ は歯肉中の可溶性免疫複合物を $\mathrm{C} 1 \mathrm{q}$ binding assay を用いて測定し, 歯周ポケットの梁さと正の相関 があることを証明した。 
今回著者らは組織固着性不溶性免疫複合物の測定に際 し, citrate buffer (pH 3.2) で組織を処理し，そこに含 まれる構成抗原である IgG を定量するという間接的な 手法を用いた。免疫複合物の定量法としては今 日 PEG 法, C1q binding assay などが一般的であるが, 実験動 物がイヌの場合, $\mathrm{C} 1 \mathrm{q}$ の精製法がヒトに比べ難しいこと, PEG 濃度の設定がヒトの場合と異なり難しいことを理 由とした。この結果, 炎症歯肉の citrate buffer 溶出画 分 (F-9) 中の IgG は健康時に比し, RIA, ELISA のどち らも有意に上昇し, しかも歯肉炎の進行に伴って増加し た。しかし, citrate buffer-elutable IgG の絶対量が PBS-elutable IgG の1/200 以下である事実からこの免 疫複合物が歯周疾患の進行にどの程度影響を及ぼしてい るかは疑問である。ただ微量ではあるが citrate bufferelutable IgG が炎症の進行に伴い増加したことは, initial lesion では白血球による免疫複合物の食食がさかん に行われたのに対し, early lesion や established lesion においては局所における白血球数の減少が免疫複合物貪 食の低下につながり, 複合物が容易に可溶化除去されに くいことを示している。一方, C3 の局在を螢光抗体法を 用いて免疫病理学的に検索した茂手木 ${ }^{21)}$ の報告による と, プラーク蓄積後 1 カ月で可溶性の免疫複合物が急激 な増加を示し, しかも結合組織中に局在していたが, 不 溶性の免疫複合物は観察されなかったとのべている。著 者らの行った免疫複合物の検索ではその構成抗原を $I g G$ のみにしぼったが, 歯肉という組織を考える以上 Ig M あるいは DNA を抗原とする免疫複合物も, 今後検討し ていく必要があるように思える。

著者らは今回 PBS-elutable ならびに citrate bufferelutable IgG 量を, 前者は SRID で後者は ELISA 及び RIAでそれぞれ測定した。SRIDは操作が非常に簡便であ る一方, 検出感度が $10 \mu \mathrm{g} / \mathrm{m} l$ と低いことから PBS-elutable IgG を定量した。citrate buffer-elutable IgG は, ごく微量であるために検出感度が数百倍も高い免疫学的 定量法として ELISA 及び RIA を用いた。著者らが行っ た ELISA は非競合的反応を利用したサンドイッチ法7) で，抗原は少なくとも二つ以上の結合部位があること, 固相化抗体と標識抗体の交叉反応がないことなどの条件 が必要であるが, IgG という安定な抗体に酵素を標識し ており，抗原結合能を失わずに微量な定量が可能である との利点がある。その上, 酵素活性は $-20^{\circ} \mathrm{C}$ で保存し ておけば 1 年以上保たれる。一方, RIA は競合的反応を 利用し, BF 分離法として二抗体法と PEG 法を組合わせ た方法を用いた。前者の二抗体法はその簡便さなどから
多く利用されている方法であるが，さらにこれに抗体の 特異性を損わずに IgG を沈殿させる PEG 法を加えるこ とにより，微量な IgG 量の測定が可能となった。 RIA は高い特異性と再現性をもち, しかも高感度 $(\mathrm{ng} / \mathrm{ml} \sim$ $\mathrm{pg} / \mathrm{m} l$ が測定可能) で, 優れた定量法といえるが, 経時 的比放射活性の低下による標識化合物の短期間使用, 実 験室や測定機器の制限など様々な問題があり, 今後は RIA と同感度の ELISA の有用性が注目されることにな ろう。

今回著者らは IgG 量の测定で ELISA と RIA を比較 したが，両者の相関性の有意さを確認し得たことから， 両者のどちらもこの citrate buffer-elutable IgG 量の測 定に有用な方法であると結論づけられる。ただし ELISA と RIA の絶対量が個々で異なり, 前者の方が若干高值 を示していたが, このことは測定法や抗体などの特性の 差, RIA における PEG 濃度などの影響が多分に考えら れる。今後はこれらの検討を十分に行い,さらにバラッ キの少ない, より簡便で精度の高い測定法を開発してい く必要がある。

\section{総括ならびに結論}

あらかじめ実験前に健康歯肉を確立したイヌの歯頸部 に絹系を結紮し, プラークの蓄積を促進させ, 各 quad$\operatorname{rant}(1 / 2$ 顎) ごとにそれぞれ 1 週, 1 力月, 3 力月病期 の歯肉炎を惹起させた。イヌを屠殺後, 歯肉組織を採取 し, これを PBS ならびに citrate buffer で溶出し, 各 画分中の IgG 量を前者は SRID で, 後者は ELISA なら びに RIA で測定した。

結果は次のとおりである。

1) 歯肉組織の PBS 溶出画分 (F-1) 中の $\operatorname{IgG}$ 量は, 健康時に比べ, プラーク蓄積 1 週, 1 力月, 3 カ月のい ずれの炎症歯肉においても増加し, 特に 3 力月との間に 統計学的に有意の差がみられた。

2) 歯肉組織の citrate buffer 溶出画分 (F-9) 中の IgG は ELISA ならびに RIA にて定量が可能となった。 健康時に比べ炎症歯肉中の含有量は有意に高く, 経時的 に増加の傾向がみられた。

3） PBS 溶出画分中の IgG 量に対する citrate buffer 溶出画分中の IgG 量の比は, 健康時に比べ炎症歯肉では 経時的に増加の傾向を示し, 特に ELISA では 1 カ月, 3 カ月病期で有意に増加していることが確認された。

4) ELISA とRIA とでは相関係数が $\mathrm{r}=0.945$ とな り，両者間に高い相関性のあることが証明された。 
謝辞

本研究の遂行に際して懇切丁寧な御教示ならびに御助言を賜 りました新潟大学脳研究所神経化学部門阿部輝雄助教授ならび に新潟大学医学部精神医学教室奥田正英先生に謹んで感謝の意 を表します。また放射性同位元素の面から御助力いただきまし た本学放射線取扱主任者水野 敞先生に厚く御礼申し上げます。 最後に本研究に御援助および御協力いただきました本学口腔生 化学教室, 歯科保存学第 2 教室員一同に深謝いたします。

本研究の一部は 1982 年 (昭和 57 年), 文部省科学研究費一般 研究B課題番号 57480351 の補助で行われたこと付記する。

\section{文献}

1) Page, R.C. and Schroeder, H.E. : Pathogenesis of inflammatory periodontal disease. A summary of current work. Lab. Invest., $33: 235-249$, 1976.

2) Okuda, K. and Takazoe, I. : Activation of complement by dental plaque. J. Periodont. Res., 15 : 232-239, 1980.

3）山下 智：イヌの実験的歯肉炎における歯肉免疫 グロブリンの動態. 日歯周誌, $24: 249 \sim 265$, 1982.

4) Ebersole, J.L., Frey, D.E., Taubman, M.A. and Smith, D.J. : An ELISA for measuring serum antibodies to Actinobacillus actinomycetemcomitans. J. Periodont. Res., 15 : 621-632, 1980.

5) Nisengard, R., Beutner, E.H., Neugeboren, N., Neiders, M. and Asaro, J. : Experimental induction of periodontal disease with Arthustype reactions. Clin. Immunol. Immunopathol., $8: 97-104,1977$.

6) Mancini, G., Carbonara, A.O. and Heremans, J.H. : Immunochemical quantitation of antigens by single radial immunodiffusion. Immunochem., 2 : 235-254, 1965.

7) Goldsmith, P.K. : A highly sensitive enzymelinked immunosorvent assay for human Immunoglobulin E:Comparison of microtiter plate and disk methodologies. Anal. Biochem., 117 : 53-60, 1981.

8）斉藤十九子 : $\mathrm{B}, \mathrm{F}$ の分離, 入江 実編, ラジオイ ムノアッセイ, 講談社, 東京, 1976, 96〜115.

9) Desbuquois, B. and Aurbach, G.D. : Use of polyethylene glycol to separate free and anti- body-bound peptide hormones in radioimmunoassays. J. Clin. Endocrinol. Metab., 33 : 732738, 1971.

10) Hunter, W.M. and Greenwood, F.C. : Preparation of iodine-131 labelled human growth hormone of high specific activity. Nature, 194 : 495-496, 1962.

11) Lowry, O.H., Rosebrough, N.J., Farr, A.L. and Randall, R.J. : Protein measurement with the folin phenol reagent. J. Biol. Chem., 193 : 265275, 1951.

12) Burton, K. : A study of the conditions and mechanism of the diphenylamine reaction for the colorimetric estimation of deoxyribonucleic acid. : Biochem. J., 62 : 315-323, 1956.

13) Lawton, A.R., Kincade, P.W. and Cooper, M.D. : Sequential expression of germline genes in development of immunoglobulin class diversity. Fed. Proc., 34 : 33-39, 1975.

14) Higuchi, Y., Honda, M. and Hayashi, H. : Production of chemotactic factor for lymphocytes by neutral SH-dependent protease of rabbit PMN leukocytes from immunoglobulins, especially Ig M. Cell. Immunol., 15 : 100-108, 1975.

15) Genco, R.J., Mashimo, P.A., Krygier, G. and Ellison, S.A. : Antibody-mediated effects on the periodontium. J. Periodontol., 45 : 330-337, 1974.

16) Roitt, I.M., Male, D.K., Hay, F.C. and Nineham, L.J. : The biological role of immune complexes. Steffen, C and Ludwig, H., Clin. Immunol. Allergol., Elsevier/North-Holland Biomedical Press, 1981, 169-195.

17) Sano, H. and Morimoto, C. : DNA isolated from DNA/anti-DNA antibody immune complexes in systemic lupus erythematosus is rich in guanine-cytosine content. J. Immunol., 128 : 1341$1345,1982$.

18) Toto, P.D., Lin, L-M. and Gargiulo, A.W. : Immunoglobulins and complement in human periodontitis. J. Periodontol., 49 : 631-634, 1978.

19) Clagett, J.A. and Page, R.C. : Insoluble immune complexes and chronic periodontal diseases in 
man and the dog. Archs. Oral Biol. 23 : 153165, 1978.

20）金城 寛：歯肉組織中の可溶性免疫複 合物 の定 量. 日歯周誌, $22: 1 \sim 10,1980$.
21）茂手木義男：イヌの実験的歯肉炎に関する免疫病 理学的研究 第 2 報 歯肉炎発生と免疫複合体に ついて. 日歯周誌, $23: 569-579,1981$. 